\title{
Transformation from Academic Majors to the Application- Oriented Ones in Key Universities
}

\author{
Dongchuan Lin \\ School of Business \\ Sichuan Agricultural University \\ Chengdu, Sichuan, China \\ Yongbing Li \\ School of Business \\ Sichuan Agricultural University \\ Chengdu, Sichuan, China
}

\author{
Jing Gao \\ School of Business \\ Sichuan Agricultural University \\ Chengdu, Sichuan, China \\ Shanxiang Liang \\ School of Business \\ Sichuan Agricultural University \\ Chengdu, Sichuan, China
}

\begin{abstract}
In recent years the government has made efforts to reform education and issued a series of policy documents about the transformation of colleges and universities. In the process of educational reform, a key university should take the initiative to play the comprehensive advantages of disciplines and talents to enhance their contribution to education reformation. This paper will explone the problems related to the transformation from academic majors to the applicationoriented ones in key universities by taking Financial Management Department of Sichuan Agricultural University as an example and then explore the new mode of talents training in the adaptation of social needs.
\end{abstract}

Keywords-applied talents; the demand for talents; professional transformation

\section{ANALYSIS OF DEMAND AND SUPPLY FOR APPLIED TALENTS}

\section{A. The Present Situation of Social Demand for Applied Talents}

The demand for talents is more and more diversified in industries and enterprises, along with the maturing and further development of our domestic economy. The market demand of the application oriented talents is also growing. In the second quarter of 2015, China's human resources market information monitoring center carried out a statistical analysis about market supply and demand information in 101 cities in the country's public employment service agency. The statistical analysis showed that about $56 \%$ of the employers had clear requirements of the technical level or title for the employees. The ratio of technical vacancies and applicants was generally greater than 1, and the demand of labor was greater than supply. Among them, the ratio of technicians, senior technicians, senior engineers, engineers' position vacancies, and applicants were large (respectively 2.0, 1.94, 1.81 and 1.77). With the further transformation and adjustment of econo mic structure, China's demand for high-skilled talents is growing fast. By 2020, 142 million high-skilled talents with higher education levels will be needed. If the skill of the workers couldn't be further developed, China will face a talent supply gap of 24 million. As it can be seen from the results, the serious lack of skilled personnel in our country and the current domestic shortage of applied technological talents is unable to meet the demand of industry and society.

\section{B. The Current Supply Condition of Talents in Colleges and Universities In China}

In recent years, there are more and more Chinese college graduates, but it is becoming more and more difficult for them to get employed. In 2014, there was 7.27 million college graduates and in 2015 there was 7.49 million college graduates, and according to the survey many enterprises found it difficult to employ enough applied technological talents that they needed. This phenomenon indicates that there is a big gap between graduates cultivated in higher education and the social demand, and that the employers' expectation for graduates and the actual performances of graduates do not match.

\section{The Necessity of Colleges and Universities Transformation}

At present, the higher education produces an excess of talent, on the other hand, the talent demand isn't well satisfied. It is the dislocation of the talent supply and demand on personnel training specification that cause the structural unemployment of college graduates, which reflects the imbalance of higher education and social politics, economy, culture and science and technology. This external disharmony will directly affect the interior of the higher education, requiring more colleges and universities to make corresponding changes in the training target, professional settings, curriculu m structure and teaching model, according to the requirements of social economy, science and technology. 


\section{POWERFUL POLICIES OF COLLEGE AND UNIVERSIT Y TRANSFORMATION AND FINANCIAL ACCOUNTING PERSONNEL TRAINING}

A. The Policy of Transformation of Part of the Subjects to Application Oriented in Colleges and Universities

"The outline of national medium and long-term education reformation and development plan (2010-2020)" is sued by the State Council in 2010, clearly put forward that the higher education should meet the needs of national and regional economic and social development and constantly optimize the structure of higher education, the structure of professional disciplines, levels and types, focusing on expanding applied, compound, skilled personnel training scale. Education department of Sichuan province in 2011 formulated the opinions about the implementation of the "higher education quality engineering," pointing out that we should reform comp rehensively in colleges and universities, to strengthen the construction of practice teaching resources, forming a batch of high-level innovative an applied and skilled talent training base.

In 2013 the ministry of education put forward the opinion on deepening the comprehensive reform in the education field, pointing out that we must increase the intensity of supporting and further promote the comprehensive reform of top creative talents in colleges and universities, encourage and support the university to explore new general education model combined with reality, carry out the training of skilled talents pilot of local colleges and universities, strengthen the practice teaching and innovation and entrepreneurship education.

In March 2014, Xu Ningsheng, member of Chinese Academy Science, ZhongShan University president proposed that comprehensive universities should play the advantages of disciplines and talents, improving their contribution to innovative national construction in comprehensively deepening reform. In addition, the education department of Sichuan province put forward guidance of deepening the comprehensive reformation in education field from the period of 2014-2020, to lead part of the ordinary undergraduate course colleges and universities to application technology type.

In June 2015, Yuan Guiren, the Minister of Education, said in a video conference on deepening the reform of higher education innovation and entrepreneurship education, that colleges and universities should promote the cooperation between the talents training programs and social needs, and promote the cooperation between the disciplines, strengthen innovation, strengthen entrepreneurship practice, and reform the teaching management system.

2015 Sichuan Provincial Education Department's work points out: we must promote the development of higher education, adjust and optimize the structure of discipline and personnel training in colleges and universities, and start the reform pilot work about some local undergraduate colleges and universities to the application of technology type.

\section{B. The Policy of Accounting's and Financial Personnel's Plan and Development}

In 2010 , the ministry of finance issued the "accounting talents program", which clearly put forward "accounting talents should obviously enhance the competitive advantage, significantly increase talent scale". In "The accounting industry long-term talent development plan (2010-2020)," the ministry of finance declared that financial departments at all levels must promote the establishment of the industryacademy-research strategic alliance which made the unit of employers as the main body and the market as the guidance, aiming to encourage and promote the professional colleges and universities to work closely with the unit of employee personnel, actively implement accounting backup talent cultivation plan, promote the accounting personnel training model, colleges and universities teaching as the main body, with unit practice as the supplement. Enterprises and institutions, public accounting firms should fulfill social responsibility, set up accounting personnel training platform and promote the training of applied talents in accounting.

In May 2014, Yang Min, the ministry of finance accounting department pointed out that we should actively promote the healthy development of the accounting professional degree graduate education, establish the accounting professional degree education quality certification system to constantly improve the quality of accounting professional degree education, push forward the "two-way link" about accounting professional degree education and accounting related professional qualification examination, and further strengthen the practice guidance about high-level accounting education.

Colleges and universities are always the basis of accounting personnel training, the main area for applied accounting, finance, and compound talents training. Personnel training should be the most basic and the most important function of colleges and universities.

\section{CHARACTERIST ICS OF THE TALENT TRAINING}

SCHEME ABOUT LEVEL 2014 FINANCIAL MANAGEMENT PROFESSIONAL IN SICHUAN AGRICULT URAL UNIVERSITY BUSINESS SCHOOL

\section{A. Professional Profile}

Sichuan Agricultural University established financial management undergraduate specialty for the first time in 2000 and since then it has seen 12 session of students graduate to become professionals. At present, the specialty is so popular that its admission score is the highest in school and the most students turn their professions into it every year. Only in May 2015, 180 of the 2014 students have transferred to financial management. There were still some outstanding alumni, some passed the ministry of foreign affairs of civil service, some became Beijing University graduate students, and one student passed six courses in the first stage examination for certified public accountants at a time who won the global internal auditor first crown. We constantly optimize the talent training scheme, which is the main and most important reason for the emergence of the 
major outstanding alumni. At the same time, the feedback from the alumni and the undergraduate students is also the important basis of professional personnel training scheme optimization.

\section{B. The Revision of the New Scheme}

On July 1, 2014 the school held a video conference about revision to the talent training scheme in 2014. Combining with the financial management specialty, we will try to set up applied financial management professional in a key university. We carried out a self-inspection to the talent training scheme in 2013, and combined with the sampling investigation to the alumni and students of the major, listened to their views and suggestions fully, and we organized professional teacher discussions, modified and formed training scheme draft, and wrote to the teaching dean about the talent training scheme (about financial management professional) PPT report content. In the Dean report meeting on July 10, the school leaders and relevant experts put forward some valuable advice with the combination of some files. They are respectively, "the specialty catalog and introduction of undergraduate courses of common colleges and universities" promulgated in 2012 by the ministry of education, the files are in regard to some universities to application-oriented professional transformation programs in 2014 , and the classification of the talents training in colleges and universities of Sichuan Province and the undergraduate professional classification of talent training scheme for revision guidance" file of school in 2014. During July 11 - July 15 , the school is sued a notice about training scheme revision "the two supplementary notice on the internship and the core backbone courses". We repeatedly called for professional teachers discussions, and communicated with the head of the relevant professionals programs, and modified and fin ished the scheme in the end. On July 16, the business school organized professional talent training scheme and revision discussions meeting. The scheme was passed and publicized through the college website after examination and approval by the dean on July 17 .

Publicized without objection, reported to the school audit after the publication, the educational program was uploaded in a timely fashion to the educational administration website. September 2014 to Ju ly 2015 is the first year of the implementation of the new program and the educational administration department and the college have organized 3 student teaching symposium to listen to the views of students, which will be reflected in the 2015 amend ments to improve the program.

\section{The Features of the New Scheme.}

The characteristics of the talent training scheme about applied financial management level 2014 is embodied in the following three aspects after repeated revision.

First, in terms of the required courses, it ensures complete coverage of professional core courses on blue book required by ministry of education, and the course names are completely consistent with the requests. "Securities Investment Theory and Practice" was replaced by "Investment Principles" with richer contents, "Finance" was replaced with more professional "Financial Market", and single practice teaching "Financial Information Analysis" was adjusted to "Financial Analysis" with related theories and experiments, which was included in the professional core backbone courses.

In addition, we also made corresponding adjustments for core courses, which are "Financial Accounting", "Financial Management", "Auditing", "Advanced Financial Management" and "Financial Analysis".

These five core courses require four credits or more and all of them are equipped with experimental courses so as to improve practical skills. On the other hand, the talent training scheme is docking with the national qualification examination. Accounting qualification examination subjects are "Fundamental Accounting", "Financial Laws and Regulations and Professional Ethics", "Accounting Computerization", certified public accountant (CPA) exam subjects are "Accounting", "Financial Management and Cost Management" "Auditing", "Economic Laws", "Taxation Laws", "Corporate Strategy and Risk Management". These courses are all set in order to improve the passing rate of students' participating in the relevant qualification exam and enhance students' professional skills and employ ment competitiveness.

In the teaching practice link, in addition to the traditional accounting and financial related course practice, we tried to drive enterprises to the campus programs under the VBSE (virtual business social environment). On the basis of the experience of the three consecutive years from 2012 to 2014 in ERP at the provincial level competition, we set up "ERP training courses" for the first time. In addition, as the applied undergraduate professional, we specially added 20 weeks of "post practice" course.

In recommended selective course link, on the one hand, we considered setting up "Assets Evaluation", "Project Evaluation" and other applied courses practicing and using the theories of finance and accounting knowledge to solve practical problems, provid ing students with new knowledge related to the financial management profession and a new direction for their employment. On the other hand, considering almost all the compulsory courses are quite professional, it is likely to influence student's vision when strengthening their skills. Therefore, according to the national call "public entrepreneurship, innovation", we set up the "Marketing", "Human Resource Management" and other management courses, which can strengthen students' cross major thinking training and lay a good foundation for the students' transformation in the future from the application of skilled professionals to management talents.

\section{THE NEW PROPOSAL EXECUTION}

\section{A. Laying Importance to Professional Guidance}

The content of "an introduction to professional" is elaborately designed to introduce the history and achievements of this major, strengthening the professional identity of new students, and planning to introduce 
Certificate of Accounting Profession, time of Certified Public Accountant examination, subjects, further education, social recognition, and other content. It aims to cultivate students' ability of bearing hardships and the steadfast spirit. It also includes the employment direction, employment channels and typical examples of employment. On the one hand, it forces new students into a rapid transition for their new roles, but more importantly, it can make those freshmen understand the university is a new beginning, not just a continuation of high school. It needs their new efforts.

\section{B. Strengthening the Professional Training Through Teaching}

We should pay attention to the knowledge of cohesion and experimental practice training. In recent years, the business school has sourced almost all teaching software for the set experimental courses, such as basic accounting simulation training platform, intermediate financial accounting practice platform, financial management practice training platform, ERP training software, etc. Especially in 2015 , our college received from the state special funds in support of construction in local colleges and we will apply the purchasing financial decision support system, audit star and other softwares to further to improve the Internet+ financial management experiment and practice teaching. In addition, we added special knowledge about agriculture and forestry in the teaching, such as adding the cooperative accounting, biological assets accounting, and other contents in advanced financial accounting course.

\section{Organizing Professional Skill Competition and Taking Part In Social Qualification Test}

Professional skill competition is not only the supplement of classroom teaching and experimental teaching, but also an important way to cultivate the students' interest in the profession and to improve the students' professional skills. So far we have organized three consecutive terms of computerized accounting, ERP sand table simulation contest, audit video game, etc. We are going to increase financial case competition, accounting skills show competition, project report preparation competition, and other new activities. In addition, the social qualification certificate is the basic requirement in employing talents, which has high social recognition. In terms of the test information, we inform students through the college website, financial management professional micro blog (Sichuan Agricultural University of Finance and audit) and the course teacher, and reward students who get good results.

\section{Organizing Students Symposium, Outstanding Alumni Feedback Meeting Regularly}

Student symposium should contain the communication of students of different grades and teaching feedback and suggestions so as to understand the students' current situation and constantly consummate the teaching and improve the teaching quality. Invite outstanding alumni to communicate with students and share the latest trend of society, work practice and requirements to make professional theoretical knowledge more practical in daily operation.

\section{E. Intensifying the Guidance on Student Practice and Graduation Thesis}

The school system in which each graduate has a tutor helps students' receive more professional guidance. In the financial management profession, there are many students participating in the National University Student Innovation Program, the plan of cultivating scientific interest, the Challenge Cup, and other activities with the guidance of teachers. Strengthen cooperation with practice bases and promote the guidance of student internship and graduation thesis to ensure the high quality of graduates.

\section{ACKNOWLEDGMENT}

We thank the support of the 2014 Provincial College Students' Innovative Entrepreneurial Training Program, grant 201410626058, the 2014 Sichuan Agricultural University School Educational Reform Project, grant X2014021, and the Sichuan Agricultural University Undergraduate Course Best Paper Breeding Program.

\section{REFERENCE}

[1] Li-Kai Chen, "China needs to grasp the demand of skilled talents," Enterprise Reform and Management, vol. 8, pp.39, 2013.

[2] Lou Chunhui, "The enlightenment of foreign skills training mode for our country,'Market Modernization, vol. 18, pp.77-79, 2007.

[3] Jeanne C. Meister, Corporate University lessons in Building a Worldclass Work Force, New York: McGraw-Hill, 1998.

[4] Zhang Xiongwu, Xu Yinxiang,"Analysis on "Responsibility sharing mechanism" of Application-oriented undergraduate training in developed countries," Jiangsu Higher Education,vol.4, pp.102-104, 2011. 